\title{
APPLICATION OF FLUID INCLUSION AND ROCK-GAS ANALYSIS IN MINERAL EXPLORATION
}

\author{
STEPHEN E. KESLER, PATRICIA S. HAYNES, MICHAEL Z. CREECH and \\ JONATHAN A. GORMAN
}

Department of Geological Sciences, University of Michigan, Ann Arbor, MI 48109, U.S.A.

(Received December 24, 1984; revised and accepted June 28, 1985)

\section{ABSTRACT}

Kesler, S.E., Haynes, P.S., Creech, M.Z. and Gorman, J.A., 1986. Application of fluid inclusion and rock-gas analysis in mineral exploration. In: C.E. Nichols (Editor), Exploration for Ore Deposits of the North American Cordillera. J. Geochem. Explor,, 25 : 201-215.

Gases are known to form haloes around presently active geothermal systems and might be useful in exploration for older, extinct hydrothermal systems. Gases from such extinct hydrothermal systems can be liberated for analysis from fluid inclusions in hydrothermal minerals by thermal decrepitation or they can be desorbed from alteration mineral surfaces by heating. The most abundant of these gases, besides $\mathrm{H}_{2} \mathrm{O}$, are usually $\mathrm{CO}_{2}, \mathrm{CH}_{4}, \mathrm{CO}$ and $\mathrm{N}_{2}$. We have used a gas chromatograph to analyze these gases in fluid inclusions in jasperoid around the Pueblo Viejo gold-silver deposit, in vein minerals from the Creede silver-lead-zinc deposit, and from clays in the alteration cap overlying veins at Creede to test for gas haloes useful in exploration. At Pueblo Viejo $\mathrm{CO}_{2}$ abundances in the jasperoid range from less than 1 mole percent (with respect to the system $\mathrm{CH}_{4}-\mathrm{CO}_{2}$ $\mathrm{CO}-\mathrm{N}_{2}-\mathrm{H}_{2} \mathrm{O}$ ) in the ore zone to as much as 6 mole percent in surrounding, barren jasperoid. Fluid inclusion analyses at Creede suggest that a drop in the $\mathrm{CO}_{2}$ content of the fluid may relate to ore deposition and clay directly above veins has large amounts of ad. sorbed $\mathrm{CO}_{2}$. These results suggest that primary gas abundances exhibit patterns in and around hydrothermal ore deposits that can be used in mineral exploration.

\section{INTRODUCTION}

Surveys have shown that gases form haloes around geothermal zones and volcanoes (Stoiber and Rose, 1974; Hinkle and Harms, 1978) and it is reasonable to assume that similar gas haloes existed around the extinct geothermal systems that generated many hydrothermal ore deposits. Records of the gases in extinct hydrothermal systems will be preserved in primary fluid inclusions in hydrothermal minerals and, possibly, as gases adsorbed on ore and alteration minerals. Variations in the relative abundances of some of these gases such as $\mathrm{CO}_{2}$ and $\mathrm{H}_{2} \mathrm{~S}$ should reflect variations in temperature, pressure, or the location of chemical processes such as boiling or wall-rock reaction, all of which can control ore deposition in hydrothermal systems 
(Drummond, 1981). Thus, gas haloes might be useful in exploration of hydrothermal systems.

Efforts to use optical studies of fluid inclusions in mineral exploration have been made by Nash (1976) and discussed by Roedder (1977). Smith and Peach (1949) attempted to apply thermal decrepitation, a bulk-inclusion analysis method, to exploration early in the history of fluid inclusion research and Burlinson et al. (1983) recently revived this approach with apparent success. In studies of gases adsorbed onto mineral surfaces, Norman (1981) found high sulfur concentrations in hydrous alteration minerals from sulfide ore deposits and Palin and Norman (1982) reported $\mathrm{CO}_{2}$ enrichment and $\mathrm{H}_{2} \mathrm{~S}$ depletion in phyllosilicate minerals above the buried Copper Flat porphyry deposit of New Mexico, while CO decreased with increasing distance from the orebody.

We report here a series of preliminary evaluations of the usefulness of fluid inclusion and rock-gas analysis to mineral exploration at the Pueblo Viejo gold-silver hot-spring deposit in the Dominican Republic and the Creede, Colorado precious and base metal veins. We have reported elsewhere on the distribution of inclusion gases in quartz veins in the Porcupine gold camp of northern Ontario, where these gases provide a strong anomaly approximately $1 \mathrm{~km}$ wide over the McIntyre-Hollinger deposit (Smith and Kesler, 1985). Bulk analysis of fluid inclusions, the method used in this study, is clearly more rapid and less expensive than traditional optical studies of fluid inclusions and it yields direct compositional data. It is subject, however, to complications caused by the analysis of a sample containing both primary and secondary inclusions where the secondary inclusions might dilute or mask the primary compositional zoning. We freely acknowledge this complication but suggest that similar problems are present in most geochemical exploration samples. The challenge in geochemical exploration is to obtain meaningful data from bulk analyses of this sort, if possible, and to go on to more costly, detailed analytical determinations only where useful data cannot be obtained less expensively. There almost certainly are many hydrothermal systems in which compositional variations in one gram samples are adequate to delineate inclusion gas anomalies and our goal at this point is to determine which deposit types, in which geological environments, yield the best anomalies and where inclusion gas analyses can be most helpful in geochemical exploration.

\section{ANALYSIS OF INCLUSION GASES}

Inclusion gases can be released for analysis either by decrepitation or crushing. In general, thermal decrepitation of inclusion-bearing material is preferable because gases released during crushing are adsorbed readily onto newly broken mineral surfaces (Barker and Torkelson, 1975). For our fluid inclusion analyses we use material crushed to $-20 /+60$ mesh. Crushed quartz 
and jasperoid samples are soaked in aqua regia overnight to remove finegrained carbonate or sulfide inclusions, which can decompose to produce gases at high temperature. Most organic material, which might produce $\mathrm{CH}_{4}$, $\mathrm{CO}_{2}$, or other gases on heating can be removed from contaminated samples by soaking in acetonitrile $\left(\mathrm{CH}_{3} \mathrm{CN}\right)$ (Alexandrovska et al., 1980). Care should be taken not to breathe acetonitrile vapor. In general the filling temperature or homogenization temperature of fluid inclusions can be used as a guide for the temperature at which the inclusion should be decrepitated for release of gases, with the decrepitation temperature being $50-100^{\circ}$ above the inclusion filling temperature (Leroy, 1979). In cases where the inclusions have not been studied optically in the material, or where confirmation of actual inclusion decrepitation temperature is desired, step-heating tests, in which the material is heated at 50 or $100^{\circ}$ intervals and released gases are analyzed can be used to determine the appropriate temperature for gas release.

For all fluid inclusion analyses reported here $1 \mathrm{~g}$ of crushed sample was decrepitated in a Vycor glass tube and the evolved gases introduced into a Tracor 560 gas chromatograph by means of a helium carrier and switching valves (Fig. 1). Samples were allowed to decrepitate for 15 minutes in a helium atmosphere. To prevent condensation of $\mathrm{H}_{2} \mathrm{O}$ during analysis all extraction lines and valves were heated to above $100^{\circ} \mathrm{C}$. Two columns were used to separate the gases: a $50-75^{\circ} \mathrm{C}$ temperature programmed 6 foot $\times 1 / 4$ " stainless steel front column, and a 3 foot $\times 1 / 4^{\prime \prime}$ stainless steel back column cooled to $-78^{\circ} \mathrm{C}$ (Fig. 2). A $-78^{\circ} \mathrm{C}$ cold trap was placed between the two columns to prevent $\mathrm{H}_{2} \mathrm{O}$ from entering the back column and to delay the passage of $\mathrm{CO}_{2}$ and $\mathrm{CH}_{4}$. Both columns were packed with 60/80 mesh Chromosorb 102 (Johns-Manville Corp.). Generally similar analytical arrangements have been used by Cuney et al. (1976), Malakhov (1977), and Behar and Pineau (1979).

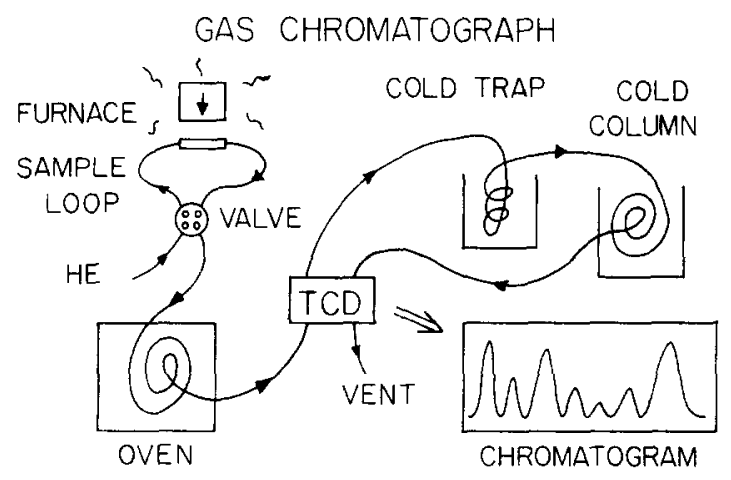

Fig. 1. Schematic diagram of gas chromatographic system. TCD $=$ Thermal Conductivity Detector. 


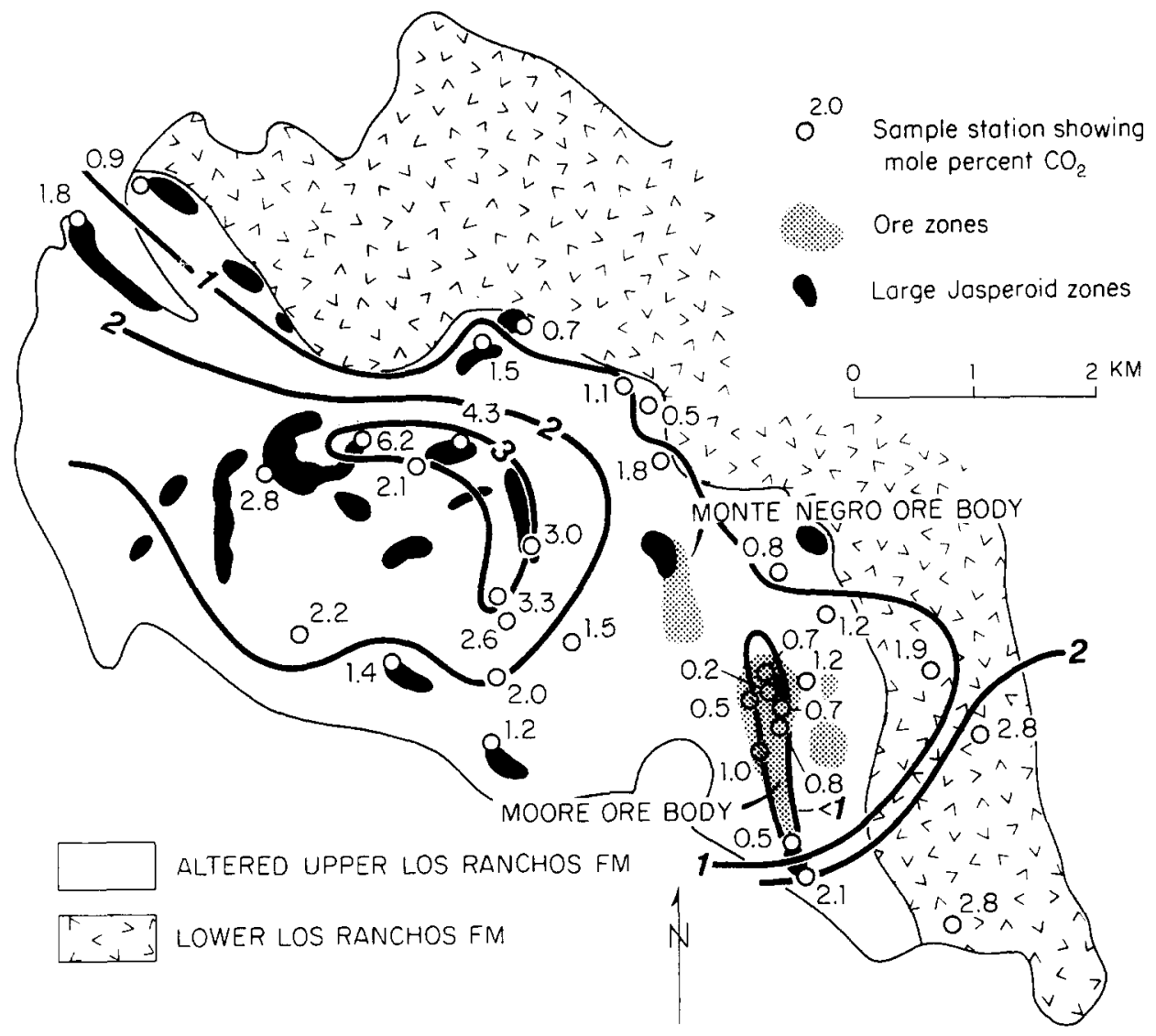

Fig. 2. Schematic geologic map of the Los Ranchos Formation showing location of Pueblo Viejo ore zones and jasperoid (after Kesler et al., 1981). Sample locations used in this study are shown along with $\mathrm{CO}_{2}$ gas contents.

In the results reported here all analyses were carried out with a Tracor thermal conductivity detector (TCD). With a helium carrier gas, a $3.5-\mathrm{ml}$ mixture (at standard $P$ and $T$ ) of $\mathrm{N}_{2}, \mathrm{CO}, \mathrm{CH}_{4}, \mathrm{CO}_{2}$ and $\mathrm{H}_{2} \mathrm{O}$ could be separated with detection limits of $10^{-9}$ moles for $\mathrm{CO}_{2}$ and $\mathrm{CH}_{4}, 7 \times 10^{-9}$ moles for $\mathrm{N}_{2}$ and $\mathrm{CO}$, and $5 \times 10^{-7}$ moles for $\mathrm{H}_{2} \mathrm{O}$. Reproducibility was $\pm 15 \%$ for $\mathrm{CH}_{4}$ and $\mathrm{CO}_{2}$ and $\pm 20 \%$ for $\mathrm{CO}, \mathrm{N}_{2}$, and $\mathrm{H}_{2} \mathrm{O}$. A standard gas mixture custom manufactured by Scott Specialty Gas Inc. (Troy, Mich.), was used to standardize for $\mathrm{N}_{2}, \mathrm{CO}, \mathrm{CH}_{4}$, and $\mathrm{CO}_{2}$ while dehydration of $\mathrm{BaCl}_{2} \cdot 6 \mathrm{H}_{2} \mathrm{O}$ provided standard amounts of $\mathrm{H}_{2} \mathrm{O}$.

PUEBLO VIEJO

Pueblo Viejo, a 125-m.y.-old gold-silver acid-sulfate deposit in the Dominican Republic, provides an excellent example of a geologic environment in 
which gas analysis could be useful in exploration. The large oxide gold-silver orebody (Russell et al., 1981) and the underlying sulfide zone (Kesler et al., 1981) are in the upper part of the early Cretaceous Los Ranchos Formation. Outcrops of the upper Los Ranchos Formation, which cover an area of about $15 \mathrm{~km}^{2}$ around the Pueblo Viejo deposit, consist of rock that has been completely altered to advanced argillic assemblages with ledges and zones of massive jasperoid (Fig. 2). Where the Pueblo Viejo deposit has been explored

\section{TABLE 1}

Bulk fluid inclusion gas analyses from Pueblo Viejo

\begin{tabular}{|c|c|c|c|c|c|c|c|c|c|}
\hline \multirow{2}{*}{$\begin{array}{l}\text { Lab } \\
\#\end{array}$} & \multirow{2}{*}{$\begin{array}{l}\text { Sample } \\
\text { number }\end{array}$} & \multicolumn{4}{|c|}{$\mu \mathrm{mole} / \mathrm{g}$} & \multicolumn{4}{|c|}{ mole \% } \\
\hline & & $\mathrm{CO}_{2}$ & $\mathrm{CO}$ & $\mathrm{N}_{2}$ & $\mathrm{H}_{2} \mathrm{O}$ & $\mathrm{CO}_{2}$ & $\mathrm{CO}$ & $\mathrm{N}_{2}$ & $\mathrm{H}_{2} \mathrm{O}$ \\
\hline 1 & RD-77-27 & 0.04 & 0.01 & 0.07 & 5.4 & 0.7 & 0.2 & 1.3 & 97.8 \\
\hline 2 & PK-7 & 0.09 & 0.02 & 0.02 & 13.0 & 0.7 & 0.2 & 0.2 & 99.0 \\
\hline 3 & $T-6-4$ & 0.20 & 0.05 & 0.12 & 17.8 & 1.1 & 0.3 & 0.7 & 97.9 \\
\hline 4 & $\mathrm{RD}-72-140$ & 0.10 & 0.03 & - & 8.0 & 1.2 & 0.3 & - & 98.4 \\
\hline $5 \neq$ & DDH-173-120 & 0.04 & 0.02 & 0.19 & 6.9 & 0.5 & 0.3 & 2.7 & 96.5 \\
\hline $6 \#$ & DDH-163-192 & 0.19 & 0.11 & - & 94.6 & 0.2 & 0.1 & - & 99.7 \\
\hline $7 *$ & RD-77-23 & 0.09 & 0.02 & 0.04 & 17.3 & 0.5 & 0.1 & 0.2 & 98.9 \\
\hline 8 & SH-1-1 & 0.05 & - & 0.04 & 6.5 & 0.8 & - & 0.6 & 98.5 \\
\hline 9 & RD-77-12 & 0.08 & 0.01 & 0.05 & 3.8 & 2.1 & 0.3 & 1.2 & 96.5 \\
\hline 10 & $\mathrm{RD} \cdot 72-130$ & 0.08 & 0.03 & 0.13 & 6.2 & 1.2 & 0.5 & 2.0 & 96.3 \\
\hline 11 & $\mathrm{RD} \cdot 72 \cdot 219$ & 0.20 & 0.06 & 0.11 & 10.1 & 1.9 & 0.6 & 1.1 & 96.4 \\
\hline $12^{*}$ & RD-72-235 & 0.05 & 0.02 & 0.02 & 5.2 & 0.8 & 0.4 & 0.4 & 98.2 \\
\hline 13 & $\mathrm{RD} \cdot 73 \cdot 249$ & 0.16 & 0.13 & 0.12 & 5.2 & 2.9 & 2.3 & 2.2 & 92.7 \\
\hline 14 & RD-77-15 & 0.24 & 0.06 & 0.03 & 8.1 & 2.8 & 0.7 & 0.3 & 96.1 \\
\hline 15 & $\mathrm{RD}-72-100$ & 0.06 & 0.02 & 0.08 & 3.2 & 1.8 & 0.5 & 2.7 & 95.1 \\
\hline 16 & RD-72-109 & 0.09 & 0.02 & 0.12 & 3.8 & 2.2 & 0.5 & 2.9 & 94.5 \\
\hline 17 & RD-73-42 & 0.06 & 0.02 & 0.13 & 4.0 & 1.5 & 0.5 & 3.1 & 94.9 \\
\hline 18 & $\mathrm{RD}-73 \cdot 108$ & 0.17 & 0.05 & 0.01 & 14.7 & 1.1 & 0.3 & 0.1 & 98.5 \\
\hline 19 & RD-72-253 & 0.18 & 0.05 & 0.08 & 5.7 & 3.0 & 0.8 & 1.3 & 94.8 \\
\hline 20 & RD-72-163 & 0.16 & 0.04 & 0.01 & 11.2 & 1.4 & 0.3 & 0.1 & 98.0 \\
\hline 21 & $\mathrm{RD}-73.172$ & 0.02 & 0.06 & 0.14 & 3.9 & 2.8 & 1.4 & 3.3 & 92.4 \\
\hline 22 & $X-2$ & 0.09 & 0.03 & 0.10 & 4.9 & 1.8 & 0.7 & 2.0 & 95.5 \\
\hline 23 & $X-3$ & 0.32 & 0.19 & 0.03 & 32.7 & 1.0 & 0.6 & 0.1 & 98.4 \\
\hline 24 & $X-5$ & 0.03 & 0.01 & 0.01 & 4.9 & 0.5 & 0.2 & 0.1 & 99.2 \\
\hline 25 & $X-6$ & 0.07 & 0.01 & 0.09 & 6.3 & 1.1 & 0.2 & 1.4 & 97.3 \\
\hline 26 & $X-7$ & 0.05 & 0.01 & 0.05 & 7.3 & 0.7 & 0.1 & 0.7 & 98.6 \\
\hline 27 & $X-8$ & 0.08 & 0.03 & 0.23 & 5.3 & 1.5 & 0.5 & 4.1 & 94.0 \\
\hline 28 & $X-9$ & 0.33 & 0.10 & 0.33 & 7.0 & 4.3 & 1.3 & 4.2 & 90.2 \\
\hline 29 & $X-10$ & 0.04 & 0.01 & 0.01 & 2.1 & 2.0 & 0.6 & 0.6 & 96.7 \\
\hline 30 & $X-11$ & 0.22 & 0.03 & 0.08 & 3.2 & 6.2 & 1.0 & 2.3 & 90.5 \\
\hline 31 & $X-12$ & 0.12 & 0.04 & 0.03 & 3.4 & 3.4 & 1.1 & 0.9 & 94.5 \\
\hline 32 & $X-13$ & 0.05 & 0.01 & 0.04 & 1.9 & 2.6 & 0.7 & 2.0 & 94.7 \\
\hline 33 & $\mathrm{X}-14$ & 0.07 & 0.02 & 0.05 & 3.2 & 2.0 & 0.5 & 1.5 & 96.0 \\
\hline
\end{tabular}

*Sample contained 0.2 mole $\% \mathrm{CH}_{4}$. All other samples contained $\leqslant 0.1$ mole $\% \mathrm{CH}_{4}$. \#Diamond drill hole samples, from depths of 120 and $192 \mathrm{~m}$. 
at depth, this jasperoid and advanced argillic alteration narrows downward to form a funnel-shaped zone that crosscuts a calcite-epidote-chlorite assemblage that resulted from earlier seafloor alteration. Samples of soil, weathered rock, and jasperoid from throughout this area of altered rock provide relatively restricted anomalies when analyzed for gold and silver.

Results of gas analyses on jasperoid samples in this area (Table 1) exhibit several systematic variations apparently related to mineralization. Note in Fig. 3 that the $\mathrm{H}_{2} \mathrm{O}-\mathrm{CO}_{2}-\mathrm{CO}$ contents of the jasperoid fluid inclusions extend from $\mathrm{H}_{2} \mathrm{O}$ toward a $\mathrm{CO} /\left(\mathrm{CO}_{2}+\mathrm{CO}\right)$ molar ratio of about 35 and that mineralized samples are definitely enriched in $\mathrm{H}_{2} \mathrm{O}$ in comparison to samples from barren areas. On a regional scale, these $\mathrm{CO}$ and $\mathrm{CO}_{2}$ values exhibit a strong concentric pattern around the Pueblo Viejo ore body with a few, as yet unevaluated, low values on the northern edge of the altered zone. Fluid inclusions from the mineralized zone at Pueblo Viejo do not contain visible $\mathrm{CO}_{2}$ (Kesler et al., 1981) in agreement with the low $\mathrm{CO}_{2}$ contents determined for them in our analyses. The presence of high $\mathrm{CO}_{2}$ in fluid inclusions in jasperoid around Pueblo Viejo cannot be verified optically because of the extremely small size of the inclusions and the opacity of the jasperoid. It is not likely that the high $\mathrm{CO}_{2}$ values observed in the jasperoid outside the ore zone resulted from the decomposition (during decrepitation) of carbonates encapsulated in the jasperoid because of the effectiveness of the acid treatment in removing carbonate and the fact that carbonate has not been observed in numerous thin sections of jasperoid. Data on solubility of $\mathrm{CO}_{2}$ in $\mathrm{H}_{2} \mathrm{O}$ (Takenouchi and Kennedy, 1965) shows that for the maximum $\mathrm{CO}_{2}$ abundances we have determined (6.2 mole percent) immiscible $\mathrm{H}_{2} \mathrm{O}$-rich and $\mathrm{CO}_{2}$-rich fluids will coexist at pressures between about 50 and 400 bars. Below 50 bars the $\mathrm{H}_{2} \mathrm{O}$ and $\mathrm{CO}_{2}$ combine to form a homogeneous gas phase.

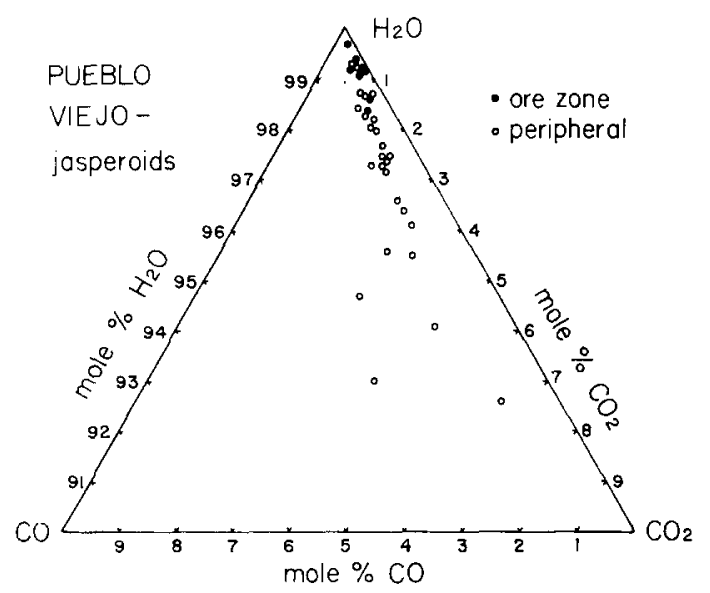

Fig. 3. Variations in $\mathrm{H}_{2} \mathrm{O}, \mathrm{CO}_{2}$, and $\mathrm{CO}$ in fluid inclusions in mineralized and barren jasperoids from the Pueblo Viejo area. 
Pressures in and around Pueblo Viejo were probably at or below 50 bars in the upper part of the deposit (Kesler et al., 1981) suggesting that these high$\mathrm{CO}_{2}$ fluids represent a gas phase permeating the upper part of the mineralizing system. The source of this $\mathrm{CO}_{2}$ is unclear at present; it could have been derived by boiling of the mineralizing solutions or by later remobilization of $\mathrm{CO}_{2}$ from underlying calcite-bearing volcanic units, which are at a shallow depth beneath areas peripheral to the Pueblo Viejo deposit, but at greater depths $(300 \mathrm{~m})$ below the ore zone (Kesler et al., 1981).

\section{CREEDE}

The Creede district is located in the Central San Juan caldera complex, part of the San Juan volcanic field of southwestern Colorado (Steven and Eaton, 1975). Silver mineralization, $24.6 \pm 0.3 \mathrm{~m} . \mathrm{y}$. in age (Bethke et al., 1976 ), occurs in a set of north-northwest-trending veins. Major production in the district has come from the Amethyst, Bulldog Mountain, $\mathrm{OH}$ and $\mathrm{P}$ veins. The northern part of the district is characterized by relatively high base metal contents and, on the $\mathrm{OH}$ vein, is capped by a thick zone of clay alteration, which becomes discontinuous just south of the area of our study on the $\mathrm{OH}$ vein (Fig. 4). Mineralization at Creede occurred in several stages (Fig. 5) now represented by individual layers in crustified veins. In the area of our study, Stage 1 layers within the veins correlate with the A stage of Bethke and Rye (1979) and are barren of silver mineralization. Stage 2a vein material (B stage of Bethke and Rye) contains the bulk of the Ag mineralization. Stage $2 \mathrm{~b}$ vein material is barren, but Stage $2 \mathrm{c}$ (D stage of Bethke and Rye) has minor silver values. The Bethke and Rye $\mathrm{C}$ stage has been recognized only in the northern parts of the $\mathrm{OH}, \mathrm{P}$, and Amethyst veins so far (Bethke and Rye, 1979) and is not represented by our Stage 2b (J.A. Gorman, unpubl. data). The clay cap that overlies this zone of mineralization is thought to have been formed when the boiling that caused ore deposition released volatiles that rose into the overlying rock and condensed to form acid water that altered the rock (Barton et al., 1977).

\section{OH-AMETHYST VEIN SYSTEM}

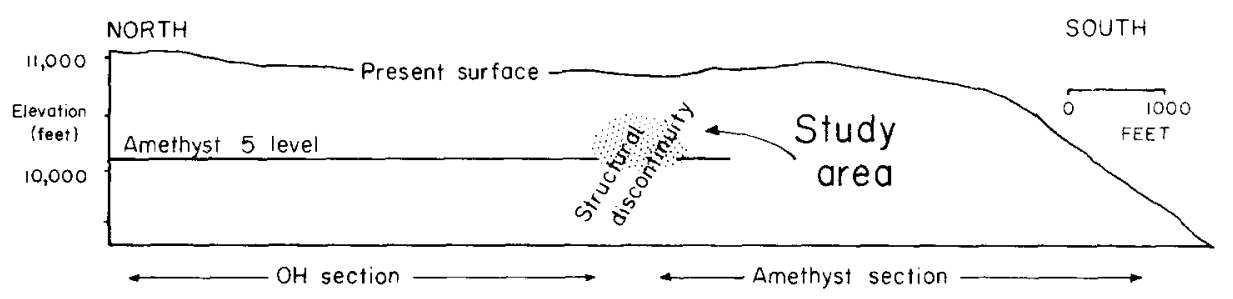

Fig. 4. Projection of the southern part of the $\mathrm{OH}$ vein and the southern Amethyst vein onto a long section, looking northeast. Amethyst 5 level shown for reference to Fig. 9 . Redrawn from Barton et al., 1977. 


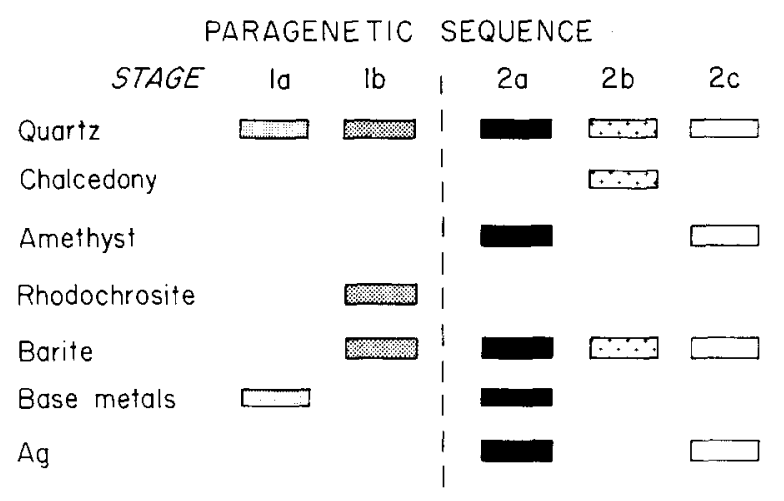

Fig. 5. Paragenetic sequence in the southern part of the $\mathrm{OH}$ vein for minerals used in this study (exclusive of illite-smectite), base metals and Ag. See text for relation of this scheme to published paragenetic sequences for other parts of the Creede vein system.

Ore shoots in the $\mathrm{OH}$ vein are effectively hidden by this clay cap and we attempted to evaluate whether gas analyses could be used to delineate zones of underlying boiling which might have produced ore shoots. To test this possibility, we analyzed both vein and clay cap material. To characterize the gas content of the mineralizing solution we analyzed fluid inclusion gases from vein quartz, chalcedony, amethyst, rhodochrosite and barite (Table 2). Note in Fig. 6 that the $\mathrm{CO}_{2} /\left(\mathrm{CO}_{2}+\mathrm{H}_{2} \mathrm{O}\right)$ ratio of gases evolved from these inclusions varies greatly. There is a sharp drop in $\mathrm{CO}_{2}$ content of the fluid from Stage 1 to Stage $2 a$ and an even further drop to the barren Stage 2b. Stage 2c samples, representing minor silver mineralization, exhibit wide variations in $\mathrm{CO}_{2}$ content. These variations are consistent with the findings of Wetlaufer (1978) who saw no geochemical difference between the early, carbonate depositing fluids (our Stage 1) and later fluids (Stage 2) except possibly higher $\mathrm{CO}_{2}$ pressures during carbonate deposition. It is not clear whether the variations in $\mathrm{CO}_{2}$ content we observe reflect boiling in the Creede system. Regardless of this uncertainty, it appears that large variations in $\mathrm{CO}_{2}$ contents of the mineralizing fluid (as indicated by our bulk inclusion analyses) correlate with precious metal deposition. Since $\mathrm{CO}_{2}$ is readily adsorbed onto mineral surfaces we have attempted to determine whether $\mathrm{CO}_{2}$ haloes could be observed in clays from the clay cap and whether their abundance could be related to the distribution of ore shoots.

The mixed layer illite-smectite (Horton, 1983) found in the clay cap at Creede is best developed in pumice fragments which are essentially completely altered. A $0.2-0.3 \mathrm{~g}$ disaggregated sample of this clay was tested for gas adsorption characteristics by heating it to $300^{\circ} \mathrm{C}$ for 30 minutes in a stream of helium to clean off adsorbed gases. This material was then split into thirds, which were treated as explained in Table 3 . The results of these tests indicate that the illite-smectite could be degassed effectively at $300^{\circ} \mathrm{C}$ and that $\mathrm{CO}_{2}$ and $\mathrm{H}_{2} \mathrm{O}$ are quickly adsorbed by the clay even at low tempera- 


\section{TABLE 2}

Bulk fluid inclusion gas analyses from Creede vein material. All samples except 2,3,5 and 20 contained a trace of $\mathrm{CH}_{4}(\leqslant 0.005 \mu \mathrm{mole} / \mathrm{g})$

\begin{tabular}{|c|c|c|c|c|c|c|c|c|}
\hline \multirow[t]{2}{*}{ Stage } & \multirow{2}{*}{$\begin{array}{l}\text { Lab } \\
\text { \# }\end{array}$} & \multirow[t]{2}{*}{ Location } & \multirow[t]{2}{*}{ Mineral } & \multicolumn{4}{|c|}{$\mu$ mole $/ \mathrm{g}$} & \multirow{2}{*}{$\frac{\mathrm{CO}_{2}}{\mathrm{CO}_{2}+\mathrm{H}_{2} \mathrm{O}} \times 100$} \\
\hline & & & & $\mathrm{CO}_{2}$ & $\mathrm{CO}$ & $\mathbf{N}_{2}$ & $\mathrm{H}_{2} \mathrm{O}$ & \\
\hline \multirow[t]{2}{*}{ 1a } & 20 & $19000 \mathrm{x}$-cut & quartz & 1.14 & 0.01 & nd & 17.5 & 6.1 \\
\hline & 22 & JAG 13 & quartz & 0.57 & 0.04 & nd & 22.8 & 2.5 \\
\hline \multirow[t]{4}{*}{$1 \mathrm{~b}$} & 14 & $19000 \mathrm{x}$-cut & rhodochr. & 1.29 & 0.01 & 0.07 & 16.8 & 7.1 \\
\hline & 15 & JAG 13 & rhodochr. & 3.90 & 0.04 & nd & 42.8 & 8.4 \\
\hline & 17 & JAG 13 & amethyst & 0.54 & 0.04 & nd & 7.0 & 7.1 \\
\hline & 18 & $19000 x$-cut & rhodochr. & 2.84 & 0.01 & nd & 38.4 & 6.9 \\
\hline \multirow[t]{5}{*}{$2 \mathrm{a}$} & 1 & JAG 1283 & quartz & 0.14 & 0.01 & 0.06 & 13.1 & 1.1 \\
\hline & 2 & DDH 25170 & amethyst & 0.05 & 0.02 & 0.03 & 4.1 & 1.2 \\
\hline & 10 & DDH 12A 121 & amethyst & 0.24 & 0.02 & 0.09 & 5.9 & 3.8 \\
\hline & 12 & JAG AMY $7-83$ & amethyst & 0.23 & 0.05 & 0.20 & 17.4 & 1.3 \\
\hline & 13 & DDH 24166 & quartz & 0.29 & 0.07 & 0.34 & 24.5 & 1.2 \\
\hline \multirow[t]{6}{*}{$2 \mathrm{~b}$} & 4 & LCD & chalcedony & 0.14 & 0.04 & 0.25 & 10.3 & 1.4 \\
\hline & 5 & DDH C45 174 & quartz & 0.07 & 0.02 & 0.06 & 37.5 & 0.2 \\
\hline & 7 & DDH 12A 138 & quartz & 0.03 & 0.01 & 0.05 & 3.3 & 0.8 \\
\hline & 8 & DDH C70 120 & quartz & 0.02 & trace & 0.05 & 4.3 & 0.4 \\
\hline & 11 & DDH C45 102 & quartz & 0.02 & 0.01 & 0.06 & 6.6 & 0.3 \\
\hline & 16 & C66 117 & barite & 0.14 & 0.02 & nd & 21.1 & 0.6 \\
\hline \multirow[t]{3}{*}{$2 \mathrm{c}$} & 9 & LCD & amethyst & trace & trace & 0.05 & 0.6 & 0.5 \\
\hline & 19 & 45 sump & amethyst & 1.07 & 0.09 & nd & 27.2 & 3.8 \\
\hline & 21 & $19000 \mathrm{x}$-cut & amethyst & 0.89 & 0.03 & nd & 3.0 & 22.8 \\
\hline
\end{tabular}

nd = not determined.

rhodochr. $=$ rhodochrosite

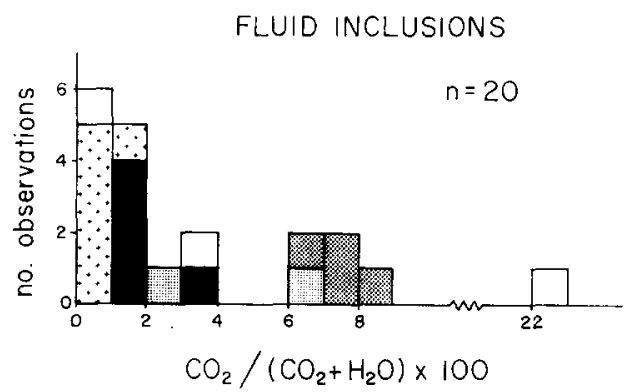

Fig. 6. Histogram of $\mathrm{CO}_{2} /\left(\mathrm{CO}_{2}+\mathrm{H}_{2} \mathrm{O}\right)$ molar ratio for 20 bulk fluid inclusion analyses on Creede vein material. Patterns are the same as were used in Fig. 5 to denote paragenetic stages. 
TABLE 3

Gases desorbed from three splits of Creede clay after it was degassed in a stream of He at $300^{\circ} \mathrm{C}$ for 30 minutes. All amounts given as $10^{-6}$ moles of gas per gram of clay

\begin{tabular}{lcccc}
\hline Conditions of further treatment & $\mathrm{CH}_{4}$ & $\mathrm{CO}_{2}$ & $\mathrm{CO}$ & $\mathrm{H}_{2} \mathrm{O}$ \\
\hline 1) heated 20 minutes at $300^{\circ} \mathrm{C}$ in helium & - & 0.2 & - & - \\
2) left overnight in lab air & 0.007 & 0.3 & - & 80.0 \\
3) left overnight in gas containing 1 mole $\%$ & & & & - \\
$\quad \mathrm{CH}_{4}, \mathrm{CO}_{2}, \mathrm{CO}$ in helium & 0.003 & 1.2 & - & - \\
\hline
\end{tabular}

tures. Step heating tests, in which gases evolved from Creede illite-smectite were analyzed at $100^{\circ} \mathrm{C}$ intervals from 100 to $500^{\circ} \mathrm{C}$ (Fig. 7) were used to determine the appropriate temperature to evolve gases from the clay for analyses. Note in Fig. 7 that very large amounts of $\mathrm{H}_{2} \mathrm{O}$ but little else were released between 100 and $200^{\circ} \mathrm{C}$ from the illite-smectite. Between 400 and $500^{\circ} \mathrm{C}$, a large amount of $\mathrm{CH}_{4}$ was released as well as some hydrocarbons not shown here. These results agree well with differential thermal analyses of clay which show the loss of loosely held water below $200^{\circ} \mathrm{C}$ but no loss of structurally bound $\mathrm{OH}$ until about $550^{\circ} \mathrm{C}$ (Mackenzie, 1957). Accordingly, we have collected and analyzed gases evolved between 200 and $400^{\circ} \mathrm{C}$ (Table

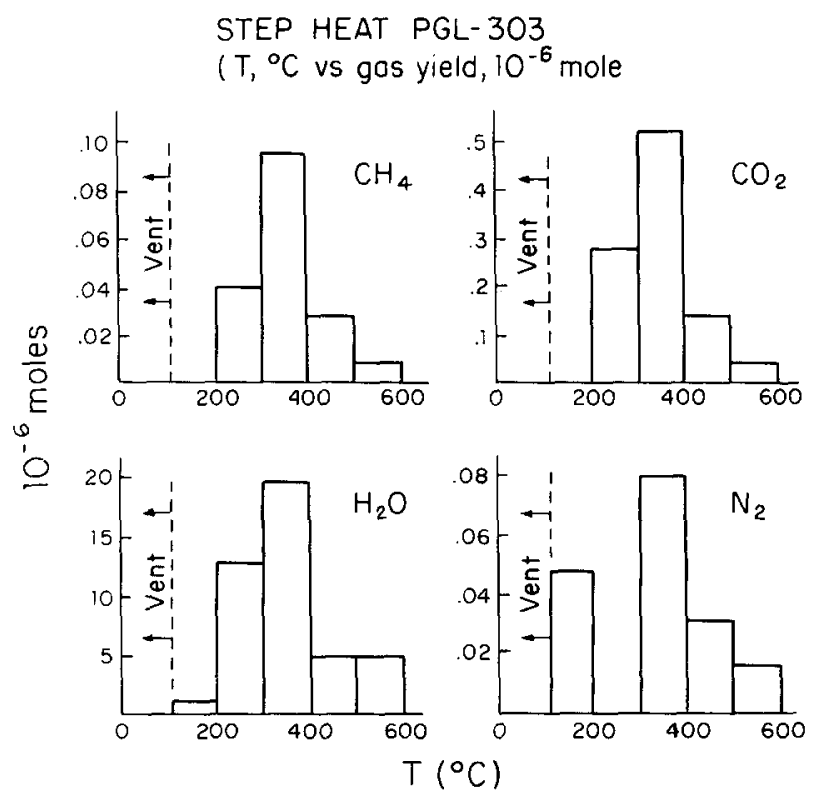

Fig. 7. Results of step-heating clay CDU 23-415. The gas evolved between 200 and $400^{\circ} \mathrm{C}$ was analyzed in this study. 
TABLE 4

Creede clay gas analyses. Nitrogen values were not determined

\begin{tabular}{|c|c|c|c|c|c|c|c|}
\hline \multirow{2}{*}{$\begin{array}{l}\text { Lab } \\
\text { \# }\end{array}$} & \multirow{2}{*}{$\begin{array}{l}\text { Drill } \\
\text { hole \# }\end{array}$} & \multirow{2}{*}{$\begin{array}{l}\text { Depth } \\
\text { (feet) }\end{array}$} & \multicolumn{4}{|c|}{$\mu \mathrm{mole} / \mathrm{g}$} & \multirow{2}{*}{$\frac{\mathrm{CO}_{2}}{\mathrm{CO}_{2}+\mathrm{H}_{2} \mathrm{O}} \times 100$} \\
\hline & & & $\mathrm{CH}_{4}$ & $\mathrm{CO}_{2}$ & $\mathrm{CO}$ & $\mathrm{H}_{2} \mathrm{O}$ & \\
\hline 1 & $\mathrm{CH} 31$ & 249 & 0.08 & 17.63 & 1.79 & 422 & 4.0 \\
\hline 2 & & 280 & 0.05 & 1.42 & 0.11 & 200 & 0.7 \\
\hline 3 & & 299 & 0.02 & 0.31 & 0.21 & 148 & 0.1 \\
\hline 4 & & 321 & 0.10 & 2.42 & 1.78 & 55 & 4.2 \\
\hline 5 & & 363 & 0.02 & 1.41 & 0.31 & 80 & 1.7 \\
\hline 6 & & 394 & 0.04 & 1.07 & 0.50 & 182 & 0.6 \\
\hline 7 & & 428 & 0.04 & 0.62 & 0.61 & 60 & 1.0 \\
\hline 8 & & 449 & 0.11 & 1.51 & 0.44 & 74 & 2.0 \\
\hline 9 & & 465 & 0.05 & 2.00 & 1.16 & 62 & 3.1 \\
\hline 10 & & 480 & 0.14 & 3.44 & 0.43 & 120 & 2.8 \\
\hline 11 & & 500 & 0.04 & 0.63 & 0.29 & 93 & 0.7 \\
\hline 12 & OHH 23 & 209 & 0.03 & 2.74 & 0.43 & 105 & 2.5 \\
\hline 13 & & 222 & 0.12 & 2.32 & 0.83 & 48 & 4.6 \\
\hline 14 & & 253 & 0.05 & 5.91 & 0.24 & 57 & 9.4 \\
\hline 15 & & 299 & 0.01 & 0.91 & 0.14 & 65 & 1.4 \\
\hline 16 & $\mathrm{OHH} 24$ & 82 & 0.04 & 1.83 & 0.18 & 54 & 3.3 \\
\hline 17 & & 137 & 0.04 & 0.96 & 0.77 & 43 & 2.2 \\
\hline 18 & & 183 & 0.04 & 0.84 & 0.28 & 66 & 1.3 \\
\hline $19 *$ & $\mathrm{OHH} \mathrm{C} 23$ & 327 & 0.04 & 2.71 & 0.59 & 133 & 2.0 \\
\hline $20 *$ & & 361 & 0.05 & 1.53 & 0.72 & 55 & 2.7 \\
\hline $21 *$ & & 387 & 0.02 & 1.38 & 0.10 & 50 & 2.7 \\
\hline $22 *$ & & 415 & 0.23 & 7.28 & 1.67 & 80 & 8.3 \\
\hline $23^{*}$ & OHH 30 & 147 & 0.04 & 1.35 & 0.37 & 108 & 1.2 \\
\hline 24 & $\mathrm{C9} 2$ & 375 & 0.03 & 2.04 & 0.99 & 29 & 6.6 \\
\hline 25 & & 404 & - & 2.87 & 0.73 & 90 & 1.2 \\
\hline 26 & & 454 & 0.03 & 1.07 & 1.61 & 90 & 2.6 \\
\hline 27 & & 526 & 0.10 & 3.94 & 0.95 & 145 & 0.6 \\
\hline 28 & & 562 & 0.02 & 0.54 & 1.86 & 96 & 1.2 \\
\hline 29 & C91 & 355 & 0.02 & 0.88 & 0.49 & 73 & 2.7 \\
\hline 30 & & 386 & 0.03 & 4.42 & 0.22 & 158 & 1.0 \\
\hline 31 & & 426 & 0.03 & 0.91 & 1.12 & 87 & 0.9 \\
\hline 32 & & 456 & 0.04 & 0.57 & 0.60 & 63 & 1.9 \\
\hline 33 & C93 & 378 & 0.06 & 1.20 & 1.09 & 63 & 1.8 \\
\hline 34 & & 440 & 0.02 & 3.96 & 3.05 & 220 & 1.1 \\
\hline 35 & $\mathrm{C} 72$ & 335 & 0.04 & 0.53 & 0.40 & 49 & 3.1 \\
\hline
\end{tabular}

*not plotted on sections.

4). Figure 8 shows the $\mathrm{CO}_{2} /\left(\mathrm{CO}_{2}+\mathrm{H}_{2} \mathrm{O}\right)$ values obtained for 35 clay samples. $\mathrm{CH}_{4}$ and $\mathrm{CO}$ were also determined on these clays but these values do not show a wide variation and are not considered further. Thirty of these $\mathrm{CO}_{2} /\left(\mathrm{CO}_{2}+\mathrm{H}_{2} \mathrm{O}\right)$ values are shown on two sections through the Creede vein system (Fig. 9). Five other samples were located 200 feet north (OHH C23 samples) or 200 feet south (OHH 30 sample) of the $19,400^{\prime}$ cross-section. 


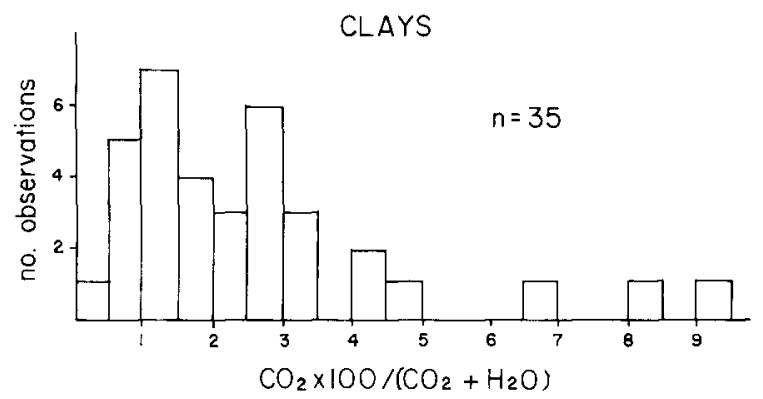

Fig. 8. Histogram of $\mathrm{CO}_{2} /\left(\mathrm{CO}_{2}+\mathrm{H}_{2} \mathrm{O}\right)$ molar ratio for 35 clay desorption analyses from Creede clay cap material
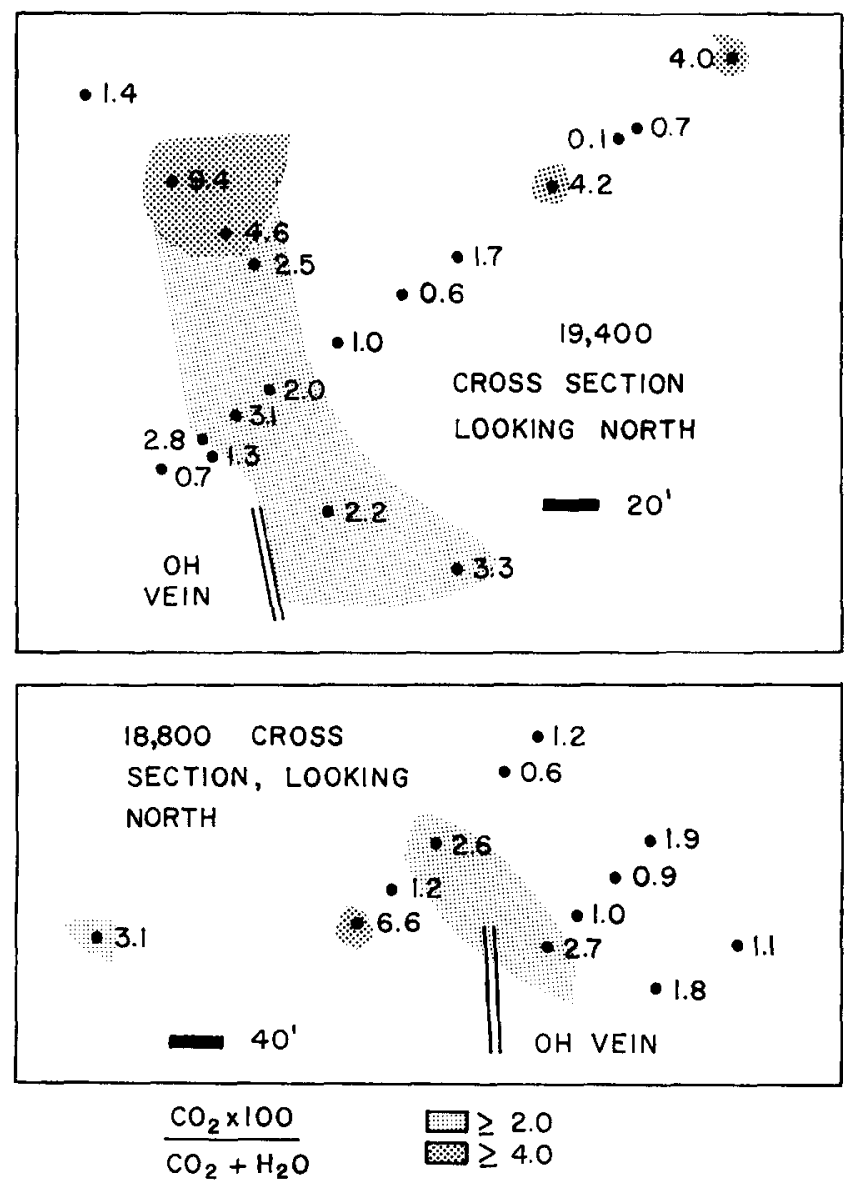

Fig. 9. Projection of subsurface drill holes to 2 east-west cross-sections on the $\mathrm{OH}$ vein. The Amethyst 5 level (see Fig. 4) is approximately $120^{\prime}$ and $240^{\prime}$ below the centers of the $19,400^{\prime}$ and $18,800^{\prime}$ cross-sections, respectively. 
The top part of Fig. 9 shows the uppermost portion of an oreshoot where it dies out and the clay cap alteration covers it. Here we see high carbondioxide values directly above the vein and intermediate to high values above and in the vein. Two high values to the north of the main vein suggest the presence of a vein split in this area. On cross-section $18,800^{\prime}$, located south of cross-section $19,400^{\prime}$ and closer to the area of structural complexity where the $\mathrm{OH}$ vein nears the Amethyst vein, the relationship is not as well observed possibly because there is a set of mineralized structures here rather than a single vein.

It is by no means certain that this $\mathrm{CO}_{2}$ enrichment in clays above and in the hanging wall around the Creede veins resulted directly from processes that formed ore in the ore shoots. Although this is an attractive explanation, it is also possible that the $\mathrm{CO}_{2}$ resulted from more recent weathering or alteration of carbonate minerals in the underlying vein system which released $\mathrm{CO}_{2}$ that accumulated in the overlying clay cap. In this case, the presence of $\mathrm{CO}_{2}$ anomalies in the clay cap would correlate with the abundance of carbonates and possibly sulfides to produce acid groundwater in the underlying vein system.

\section{CONCLUSIONS}

The gas analysis surveys described here demonstrate that wide compositional variations are observed in gases from fluid inclusions and in clays developed by alteration, and that these compositional variations can be correlated with the distribution of mineralization in the systems. It appears that these gas patterns are relatively subtle, with peak to background ratios of 2 to 10 and therefore that they could be most useful in conjunction with other geochemical or geophysical surveys or in areas where more conventional surveys provide no guidance.

\section{ACKNOWLEDGEMENTS}

We are grateful to the operating companies at the properties discussed here, Rosario Dominicana and Pioneer Nuclear, for support during sample collection. Assistance with various aspects of the analyses and interpretations was kindly provided by P.L. Cloke and M. Gardner.

\section{REFERENCES}

Alexandrovska, E.S., Bannikova, L.A. and Sushchevskaya, T.M., 1980. Errors in gas analysis in thermal expansion of inclusions. Geokhimya, 1980, pp. 1710-1716 (in Russian, translated in Geochem. Int., 17:66-71).

Barker, C.G. and Torkelson, B.E., 1975. Gas adsorption on crushed quartz and basalt. Geochim. Cosmochim. Acta, 39: 212-218. 
Barton, P.B., Jr., Bethke, P.M. and Roedder, E., 1977. Environment of ore deposition in the Creede mining district, San Juan Mountains, Colorado: Pt. III. Progress toward interpretation of the chemistry of the ore-forming fluid for the $\mathrm{OH}$ vein. Econ. Geol., 72: $1-24$.

Behar, F. and Pineau, F., 1979. Analyse de $\mathrm{CO}_{2}, \mathrm{H}_{2} \mathrm{O}$, hidrocarbones des inclusions fluides par chromatographie en phase gazeuse: Application aux fentex Alpines et aux noches metamorphiques. Bull. Mineral., 102: 611-621.

Bethke, P.M., Barton, P.B., Jr., Lanphere, M.A. and Steven, T.A., 1976. Environment of ore deposition in the Creede mining district, San Juan Mountains, Colorado. II. Age of mineralization. Econ. Geol., 71: 1006-1011.

Bethke, P.M. and Rye, R.O., 1979. Environment of ore deposition in the Creede mining district, San Juan Mountains, Colorado: Part IV. Source of fluids from hydrogen, oxygen, and carbon isotope studies. Econ. Geol., 74: 1832-1851.

Burlinson, K., Dubessy, J.C., Hladky, G. and Wilkins, R.W.T., 1983. The use of fluid decrepitometry to distinguish mineralized and barren quartz veins in the Aberfoyle tintungsten mine area, Tasmania. J. Geochem. Explor., 19: 319-333.

Cuney, M., Pagel, M. and Touret, J., 1976. L'analyse des gaz des inclusions fluides par chromatographie en phase gazeuse. Bull. Soc. Fr. Minéral. Cristallogr., 99: 169-177 (abstract in English).

Drummond, S.E., Jr., 1981. Boiling and mixing of hydrothermal fluids: chemical effects on mineral precipitation. Ph.D. thesis, Univ. of Arizona, $380 \mathrm{pp}$. (unpubl.).

Hinkle, M.E. and Harms, T.F., 1978. $\mathrm{CS}_{2}$ and $\mathrm{COS}$ in soil gas at the Roosevelt Hot Springs known geothermal resource area, Beaver County, Utah. J. Res. U.S. Geol. Surv., 6: $571-578$.

Horton, D., 1983. Argillic alteration associated with the Amethyst vein system, Creede mining district, Colorado. Ph.D. thesis, Univ. of Illinois at Urbana-Champaign, 335 pp. (unpubl.).

Kesler, S.E., Russell, N., Seaward, M., Rivera, J., McCurdy, K., Cumming, G.L. and Sutter, J.F., 1981, Geology and geochemistry of sulfide mineralization underlying the Pueblo Viejo gold-silver oxide deposit, Dominican Republic. Econ. Geol., 76: 10961117.

Leroy, J., 1979. Contribution à l'étalonnage de la pression interne des inclusions fluides lors de leur décrépitation. Bull. Mineral., 102: 584-593.

Mackenzie, R.C. (Editor), 1957. The Differential Analysis of Clays. Min. Soc., London.

Malakhov, V.V., 1977. Investigation of gas-liquid inclusions in minerals by gas chromatography. Geokhimya, 8: 1192-1198 (in Russian; translated in Geochem. Int., 14(4): $142-147$.

Nash, J.T., 1976. Fluid inclusion petrology - data from porphyry copper deposits and applications to exploration. U.S. Geol. Surv., Prof. Pap. 907-D, 16 pp.

Norman, D.I., 1981. Gases in the mica minerals: A possible exploration tool for hydro thermal ore deposits (abstr.). Geol. Soc. Am., Abstr. with Programs, 13 (7): 520.

Palin, J.M. and Norman, D.I., 1982. Volatiles in phyllosilicates, Copper Flat Porphyry Deposit, southwest New Mexico - A potential exploration tool. Geol. Soc. Am., Abstr. with Programs, 14(4): 223.

Roedder, E., 1977. Fluid inclusions as tools in mineral exploration. Econ. Geol., 72: 503-525.

Russell, N., Seaward, M., Rivera, J.A., McCurdy, K., Kesler, S.E. and Cloke, P.L., 1981. Geology and geochemistry of the Pueblo Viejo gold-silver oxide ore deposit, Dominican Republic. Trans., Inst. Min. Metal., Sec. B., 85: B153-B162.

Smith, F.G. and Peach, P.A., 1949. Apparatus for the recording of decrepitation in minerals. Econ. Geol., 44: 449-454.

Smith, T.J. and Kesler, S.E., 1985. Wallrock alteration, lithogeochemical and fluid inclusion zonation patterns at the McIntyre--Hollinger gold deposit, Timmins, Ontario. Can. Inst. Min. Metall., 34: 85-94. 
Steven, T.A. and Eaton, G.P., 1975. Environment of ore deposition in the Creede mining district, San Juan Mountains, Colorado: I. Geologic, hydrologic and geophysical setting. Econ. Geol., 70: 1023-1037.

Stoiber, R.E. and Rose, W.I., Jr., 1974. Cl, F, and $\mathrm{SO}_{2}$ in Central American volcanic gases. Bull. Volcanol., 37: 454-460.

Takenouchi, S. and Kennedy, G.S., 1965. The solubility of carbon dioxide in NaCl solutions at high temperatures and pressures. Am. J. Sci., 263: 445-454.

Wetlaufer, P.H., 1978. Chemical similarities of hydrothermal fluids from diverse sources, Creede $\mathrm{Ag}-\mathrm{Pb}-\mathrm{Zn} \cdot \mathrm{Cu}$ district, San Juan Mountains, Colorado. Geol. Soc. Am., Abstr. Programs, 10(6): 515. 